\title{
Work, Family, and Class Values in the Nineteenth Century Colloquium on Denis Poulot's Le Sublime
}

\section{David Montgomery Iver Bernstein}

Yale University

Denis Poulot (b. 1832) was a worker who became a small-time employer in the Parisian metal trades. His Le Sublime, ou le travailleur comment il est en 1870 et ce qu'il peut être offers remarkable insights into the lives, labor, and families of his former comrades. Considered a classic by social and labor historians, Le Sublime has recently been republished by Éditions Maspero with an introduction by Alain Cottereau. This new edition served as the basis of discussion at a one-day colloquium in New Haven on March 27, 1981 sponsored by the Council on West European Studies and the Department of History at Yale University. The participants included France specialists as well as historians of other European countries and the United States. The gathering signified the increasing interest of students of nineteenth century workers' movements in the world of the mid-century middle class and its relationship to working class experience.

Christopher Johnson began the morning session with remarks on Poulot's manipulation of the artisan ideologies of the eighteen forties in Le Sublime. Johnson demonstrated how Poulot reoriented artisan ideology away from its original cooperative, fraternal mold and set it in a competitive one while retaining almost all the old panaceas: political democracy, generalized primary education followed by solid vocational training in state-financed schools, chambres syndicales, organized hiring practices through craft-run hiring halls, the institutions and values of the compagnonnages, reformed Conseils des Prudhommes, and the linchpin, cooperation of production financed by cooperative banques du travail. Johnson went on to suggest that Poulot presented "a remarkably coherent progressive capitalist program for what John Foster calls 'liberalization,' ' and concluded by questioning the extent to which Poulot's ideology of management had triumphed in France in this period. 
With Johnson's remarks as a framework, the morning segment of the discussion revolved around the political world of Le Sublime. David Montgomery pointed out that Poulot, like Horace Greeley in the United States, belonged to the important bourgeois type of the radical democrat, and that both these figures stood at the historic watershed where bourgeois revolution gave way to working class initiatives. Drawing out the analogy between Poulot and the American Radical Republicans, Montgomery discussed how these mid-century middle class radicals saw their revolution (1848 in France, the Civil War in America) as history's last true revolution, after which any uprising by the working class was reactionary, or pure chaos. In their view, the path to solving "the social question" passed through self-help and the family. At the work place, the radical democrat employer could only influence limited aspects of working life because he was utterly dependent on the skills of artisans like "les sublimes," Poulot's boisterous metal workers. Montgomery suggested that in the United States, men like Poulot remained important in the labor movement through the Knights of Labor years, and that to understand workers' behavior and ideology in this period, we must also come to terms with the middle class world of Poulot.

Subsequent discussion focussed on the meetings and vocabulary of workers after the Revolution of 1848. Inspired by Bob Herbert's discussion of the euphemisms in French popular songs of the period, Susanna Barrows and Dorothy Thompson discussed the ways in which class struggle is expressed in argot and mentioned some sources for studying such language (magistrates court records, dictionaries of argot, letters of artists discussing cafe slang). Sean Wilentz pointed out the danger of overemphasizing the historical study of language and reducing class struggle to its verbal expressions. Montgomery and Thompson explored examples of how workers manipulated language with an eye to their audience, and stressed the need to understand context and innuendo in reading working-class texts. This led to speculation that perhaps even some of Poulot's so-called ouvriers vrais drank heavily behind his back.

After lunch Susanna Barrows held the floor for about an hour with an informative overview of drink and politics in the $1870 \mathrm{~s}$, much of which can be found in her book on drink and the Commune, and gave the participants a context in which to place Poulot's analysis of the cafe and drinking culture of "les sublimes." She described how the cafe of the Second Empire occupied the social space between household and work, providing a spot where the same people gathered several times daily for food, sociability, exchange of news, quest of employment, political meetings, and inculcation of the ways of their trades. Barrows' discussion addressed the increasing routinization of working-class drinking during the nineteenth century, the ways in which cafe discourse represented the mobilization of collectivity through its codes and rituals, the separate world of women's drinking, and the region and trade-specific nature of cafe clientele. Dorothy Thompson noted the importance of working-class temperance movements in England and asked what made French experience so different. Sean Wilentz placed the question in the context of the dialogue between workers' movements 
and evangelism in the Protestant countries, and Leslie Moch noted that French Protestants often took up the crusade against drink. But Barrows insisted that by the end of the 1870 s at least, the crusade against drink was so intimately associated with political repression of the working class in France that temperance agitation disappeared from the socialist movement without a trace almost until the twentieth century.

The final hour-and-a-half of the colloquium included an evaluation of Cottereau's tables linking forms of male-female and familial relations with types of workers à la Poulot, and a general discussion of the place of the middle decades of the 19th century in the transformation of working-class life and consciousness. There was general agreement that while Cottereau inspired a new and more complex understanding of working-class family economies, his attempt to link one style of sexual and family life to a corresponding type of worker did not work. Temma Kaplan insisted that one must analyze the very separate lives of men and women, and not try to understand one simply in terms of the other, as Poulot tried to do. The concluding remarks of the afternoon concerned the collective memory of the working class and the role of the French bourse du travail in introducing newcomers to that memory. That institution, so conspicuously absent from the Anglo-Saxon world, was described by Barrows as the product of a fortunate conjuncture of an opportunist republic with local traditions of working-class radicalism. 